Henderson, G. 1969: Oil and gas prospects in the Cretaceous-Tertiary basin of West Greenland. Rapp. Grønlands geol. Unders. 22, $63 \mathrm{pp}$.

Henderson, G. 1976: Petroleum geology. In Escher, A. \& Watt, W. S. (edit.) Geology of Greenland, 488-505. Copenhagen: Geol. Surv. Greenland.

Henderson, G., Rosenkrantz, A. \& Schiener, E. J. 1976: Cretaceous-Tertiary sedimentary rocks of West Greenland. In Escher, A. \& Watt, W. S. (edit.) Geology of Greenland, 340-362. Copenhagen: Geol. Surv. Greenland.

Hitchon, B. 1974: Application of geochemistry to the search for crude oil and natural gas. In Levinson, A. A. (edit.) Introduction to Exploration Geochemistry. Calgary: Applied Publishing:Co.

Kötter, K. 1960: Die mikroskopische Reflexionsmessung mit dem Photomultiplier und ihre Anwendung auf die Kohlenuntersuchung. Breninstoff-Chemie 41, 263-272.

Philippi, G. T. 1974: The influence of marine and terrestrial source material on the composition of petroleum. Geochim. cosmochim. Acta 38, 947-966.

Schiener, E. J. 1974: Geological and geophysical work between $69^{\circ} \mathrm{N}$ and $72^{\circ} \mathrm{N}$, central West Greenland. Rapp. Gronlands geol. Unders. 65, 23-26.

Schiener, E. J. 1975: Basin study: central West Greenland onshore Cretaceous-Tertiary sediments. $9 t h$ int. Congr. Sedimentology 5, 2, 379-385.

Staplin, F. L. 1969: Sedimentary organic matter, organic metamorphism and oil and gas occurrence. Bull. Can. Petrol. Geol. 17, 47-66.

Stevens, N. B. H. \& Perch-Nielsen, K. 1973: Sampling for oil source rock analysis, Scoresby Sund region, central East Greenland. Rapp. Gronlands geol. Unders. 55, 47-48.

Stevens, N. B. H., Wissema, G. G. \& Piérart, P. 1974: Report on the microfossil contents, microlithological features and source rock properties of sediments in central West Greenland. GGU Open File Report 74-1, 40 pp.

Vassoevitch, N. B., Korchagina, Yn. I., Lopatin, N. V. \& Chernyshev, V. V. 1970: Principal phase of oil formation. Int. Geol. Rev. 12, 1276-1296.

\title{
Age relations of the Precambrian Mârmorilik Marble Formation, central West Greenland
}

\author{
Adam A. Garde and T. C. R. Pulvertaft
}

The Mârmorilik Formation is one of the most important metasedimentary formations in the Precambrian of Greenland. It is the host rock of the Sorte Engel (Black Angel) zinc-lead ore body, it is the largest potential source of calcite limestone in West Greenland, and it is a striking marker horizon which greatly facilitates the recognition of major structures in the Precambrian basement. The formation is composed almost entirely of carbonate rock (dolomite and calcite marbles), and the original depositional thickness of these rocks has been estimated to be more than $1 \mathrm{~km}$ (Henderson \& Pulvertaft, 1967) an order of thickness that one of us (A.A.G.) has confirmed during recent detailed mapping south-east of Mârmorilik. 
It is known that the Mârmorilik Formation is at least 1.7 b.y. old, and one of the implications of the regional interpretation of the Umanak area given by Henderson \& Pulvertaft (1967) is that the formation may be very much older than this and perhaps Archaean; since it was regarded in that account as an integral part of the basement on which the, presumed Lower Proterozoic, Karrat Group was deposited.

Interest in the age of the Mârmorilik Formation stems from the fact that carbonate formations as thick as this one are not known from the Archaean, first appearing in the stratigraphic record about 2.2 b.y. ago. Carbonates as a whole form only a very small proportion of Archaean sediments (Ronov, 1964). So if the Mârmorilik Formation could be proved to be Archaean it would be unique, and would be an important source of information on the geochemistry of the oceans in Archaean time.

With a view to clarifying the all-important question of the age of the Mârmorilik Formation, we have carefully examined its contacts with the surrounding rocks in most places where these are accessible, and have collected material for radiometric dating which, we hope, will establish maximum and minimum limits for the time of deposition of the formation.

Our observations, made independently, contradict the interpretation of Henderson \& Pulvertaft (1967). The Mârmorilik Formation is not an integral part of the gneiss complex (in the way, for example, many of the amphibolite horizons obviously are), but is surrounded entirely by older rocks on which it was deposited, and into which it has been down-folded and thrust by at least two phases of deformation. Our reinterpretation is based partly on evidence of unconformity between the Mârmorilik Formation and the surrounding gneisses and granites, and partly on the character of the sediments along the margin of the Mârmorilik Formation.

Discordant relations between the Mârmorilik Formation and the surrounding rocks have been observed on both regional and outcrop scale. A major discordance has been mapped south-west of Mârmorilik where the margin of the Mârmorilik Formation cross-cuts the contact between very coarse-grained granodiorite to the east and homogeneous biotite gneiss to the west at an angle of almost $90^{\circ}$. Discordance on a smaller scale can be seen in this area where the base of the Mârmorilik Formation cuts across up to $4 \mathrm{~m}$ thick sheets of fine-grained granite in the coarse granodiorite.

To the west, at Magdlak, the lower contact of the Mârmorilik Formation is strikingly discordant to the structures in the contorted migmatitic nebulitic gneiss below and also cross-cuts the fine-grained granitic sheets that are common in the nebulitic gneiss. Within - $0.5-4 \mathrm{~m}$ of the margin of the Mârmorilik Formation, the nebulitic gneiss shows a foliation parallel to the base of the Mârmorilik Formation, but this does not detract from the overall picture of discordance.

Along its upper contact at Magdlak, the Mârmorilik Formation is overlain by gneiss. The degree of exposure here is poor by West Greenland standards, and relations between the Mârmorilik Formation and the overlying gneiss are further obscured by thrusting and folding. This contact provided no unequivocal evidence concerning the age relations of the Mârmorilik Formation; all the complexities of outcrop pattern appear to be of tectonic origin rather than due to the intrusion of granitic sheets into the Mârmorilik Formation.

The contacts of the Mârmorilik Formation on the Nunârssugssuaq peninsula are for the most part inaccessible. The lower contact is however well exposed in the high cliffs on the 


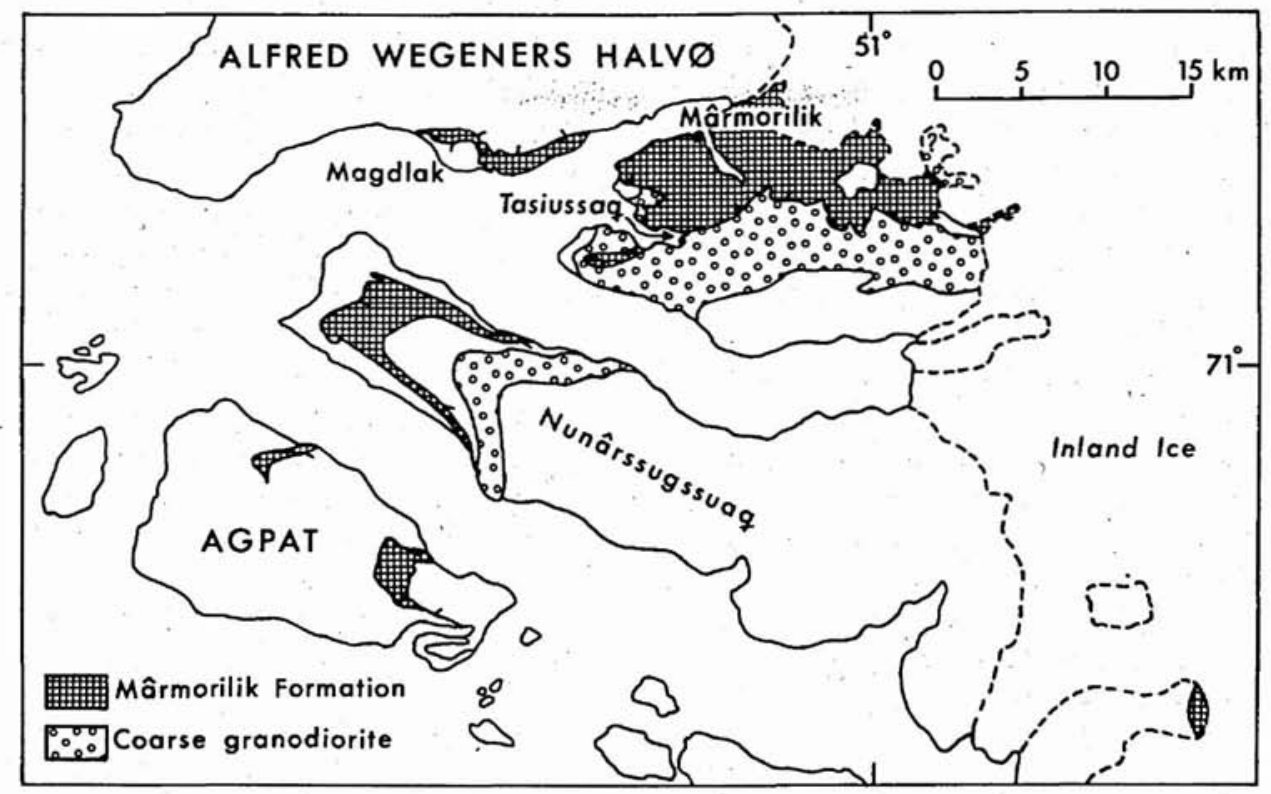

Fig. 17. Map showing the outcrop of the Mârmorilik Formation, central West Greenland, and the localities mentioned in the text. Crossmarks on the contact of the Mârmorilik Formation indicate direction of dip.

western corner of the peninsula. With binoculars one can see clearly that along this contact the Mârmorilik Formation is discordant to the general structure in the gneiss below. There are a few large, strongly discordant, leucocratic, presumably pegmatite veins in the gneiss that stop abruptly just below the base of the Mârmorilik Formation. It seems as if these veins have been shorn off by shearing in a thin zone in the gneiss along the contact of the Mârmorilik Formation. No leucocratic veins have been seen cutting the Mârmorilik Formation either here or anywhere else in the area.

The sediments at the base of the Mârmorilik Formation are best preserved in the area south-east of Mârmorilik, where the basal succession can be traced continuously for about $10 \mathrm{~km}$. Along this stretch the rocks lying directly on the coarse granodiorite are pure quartzites. These are 5-10 m thick, and are overlain by $20-30 \mathrm{~m}$ of semipelitic and siliceous schists and flags, calc-silicate rocks, impure marbles and local conglomerates, which in turn are overlain by the main marbles of the formation. Both right-way-up current bedding and wave ripple marks have been observed in the basal quartzites. Local pockets of conglomerate occur in the quartzite about $1 \mathrm{~m}$ above the base of the formation; the cobbles in the conglomerates are exclusively of fine-grained quartzite. Thus the lowermost rocks of the Mârmorilik Formation are very stable sediments of a type commonly found when a transgression has taken place over an old peneplained landscape.

The sequence in the lowest rocks of the Mârmorilik Formation at its lower contact in the Magdlak area is similar to the basal succession south-east of Mârmorilik, and at the upper 
contact one sees much the same sequence in reverse. This, together with the evidence of angular unconformity at the lower contact, indicates that the margin of the Mârmorilik Formation at Magdlak is the stratigraphic base of the formation. Consequently the structure here must be synclinal, and not the northward-facing closure of a recumbent anticline as depicted by Henderson \& Pulvertaft (1967, fig. 1a).

East of Mârmorilik the gross structure is also synclinal, since the very coarse-grained granodiorite borders the Mârmorilik Formation not only to the south but also to the north, and much the same basal succession is seen on the north flank of the marble outcrops as has been described from the south flank.

The information presented in the foregoing paragraphs constitutes in our opinion a considerable body of evidence favouring a reinterpretation of the Mârmorilik Formation as a sedimentary sequence deposited unconformably on the surrounding granite-gneiss complex. This granite-gneiss complex is believed to be Archaean, on account of certain resemblances it bears to the Archaean complex of the Godthåb-Fiskenæsset region to the south (Pulvertaft, 1973 , p. 537), so the Mârmorilik Formation is most likely post-Archaean. On the other hand it must be more than 1.7 b.y. old, since $\mathrm{K}-\mathrm{Ar}$ age determinations on biotites from the surrounding rocks (Larsen \& Møller, 1968) show that metamorphism and deformation in the area had ceased by this time.

The question now arises as to what is the relation of the Mârmorilik Formation to the metasediments of the Karrat Group which are believed to have been deposited on the same gneissic basement as the Mârmorilik Formation.

The most likely correlative of the Mârmorilik Formation is the Qeqertarssuaq Formation, the lower formation of the Karrat Group. Thin marbles occur in the quartzites of the Qeqertarssuaq Formation in the type area. The formation is characterised by rapid lateral changes in facies and thickness; the thickness decreases from $3 \mathrm{~km}$ north of Kangigdleq to a few tens of metres in Kangerdluarssuk fjord, $20 \mathrm{~km}$ north-west of Mârmorilik. It may be that during sedimentation a barrier ridge in the Inukavsait-Kangerdluarssuk area separated two basins of sedimentation - one to the north in which the dominantly terrigenous clastics of the Qeqertarssuaq Formation were laid down, and one to the south in which carbonates were deposited with only very minor influxes of terrigenous material.

Finally, what is now the status of the Nunârssugssuaq nappe, which figures so prominently in the arguments that Henderson \& Pulvertaft (1967, p. 18) presented in favour of the hypothesis that the gneisses of the Umanak region constituted a basement on which the Karrat Group was deposited? The structure certainly exists, but it can no longer be used as evidence in any discussion on gneiss-metasediment relations. Since it involves the Mârmorilik Formation, it must be a relatively young structure that, like other recumbent folds in the Umanak gneiss (Pulvertaft, 1973), quite probably formed after the deposition of the Karrat Group. Furthermore the overlap of the structure need be no more than $30 \mathrm{~km}$, and not $60 \mathrm{~km}$ as originally proposed.

\section{Acknowledgements}

We wish to acknowledge the support we have received for our field work from Greenex A/S (A.A.G.) and Statens naturvidenskabelige Forskningsråd (Danish Natural Science Research Foundation) (T.C.R.P.). 


\section{References}

Henderson, G. \& Pulvertaft, T. C. R. 1967: The stratigraphy and structure of the Precambrian rocks of the Umanak area, West Greenland. Meddr dansk geol. Foren 17, 1-20.

Larsen, O. \& Møller, J. 1968: Potassium-argon studies in West Greenland. Can. J. Earth Sci. 5, 683-691.

Pulvertaft, T. C. R. 1973: Recumbent folding and flat-lying structure in the Precambrian of northern West Greenland. Phil. Trans. R. Soc. Lond. A 273, 535-545.

Ronov, A. B. 1964: Common tendencies in the chemical evolution of the Earth's crust, ocean and atmosphere. Geochem. int. 1, 713-737.

Institut for almen Geologi, University of Copenhagen,

$\emptyset$ stervoldgade 10, 1350 Copenhagen $K$.

\section{Continued environmental studies in the Qaumarujuk and Agfardlikavsâ fjords, Mârmorilik, Umanak district, central West Greenland}

\section{Gert Asmund, Haldis J. Bollingberg and Jan Bondam}

The results of studies of the heavy metal background level in the natural environment of the Qaumarujuk and Agfardlikavsâ fjords, adjacent to the lead-zinc mine Sorte Engel (= Black Angel) near Mârmorilik ( $\left.71^{\circ} 07^{\prime} \mathrm{N}, 51^{\circ} 16^{\prime} \mathrm{W}\right)$, have been briefly communicated by Bondam \& Asmund (1974), Asmund (1975), Bohn (1975) and Bollingberg (1975). Full details of the analytical results of these surveys have been reported in Danish elsewhere. (Vandkvalitetsinstituttet 1972; Grønlands Fiskeriundersøgelser et al., 1974; GGU et al., 1975).

Since then, renewed sampling has been carried out, both in February and August 1974, and in April and September 1975, in order to follow closely the environmental dissemination of some heavy metals in the fjord region, due to disposal of tailings from the flotation plant adjacent to Agfardlikavsâ fjord (fig. 18).

This short communication deals with the content of certain heavy metals of bottom sediments, biological tissues and samples of sea water in the fjord regime after full production started in October 1973.

The tailings of the flotation plant at Mârmorilik are currently being dumped in the outer part of Agfardlikavsâ, which is separated from Qaumarujuk by a sill at a depth of $21 \mathrm{~m}$. From the start of operations in October 1973, until the 1st of January 1975, approximately 450000 metric tons of tailings have been dumped. The average heavy metal content of the solids in the tailings is currently $1.3 \% \mathrm{Zn}, 0.37 \% \mathrm{~Pb}, 0.037 \% \mathrm{Cu}$ and $0.006 \% \mathrm{Cd}$. The liquid of the tailings contains $1.6 \mathrm{ppm} \mathrm{Zn}, 0.9 \mathrm{ppm} \mathrm{Pb}, 0.5 \mathrm{ppm} \mathrm{Cu}$ and $0.7 \mathrm{ppm} \mathrm{Cd}$; approximately $6 \mathrm{~m}^{3}$ of sea water is used for each metric ton of solid waste. The effects of solid waste disposal of this magnitude on the fjord regime has shown to be detectable at an appreciable distance from the source after only two years of operation. 